\begin{tabular}{|c|l|}
\hline Title & Larval morphology of A mphiops mater mater Sharp (Coleoptera: Hydrophilidae: Chaetarthriini) \\
\hline Author(s) & Minoshima, Y ûsuke; Hay ashi, Masakazu \\
\hline Citation & $\begin{array}{l}\text { Zootaxa, 3351, 47-59 } \\
\text { https://doi.org/40.11646/_ootaxa.3351.1.5 }\end{array}$ \\
\hline Issue Date & 2012-06-19 \\
\hline Doc URL & http://hdl.handle.net/2115/49689 \\
\hline Type & article(author version) \\
\hline File Information & Zoo3351_47-59.pdf \\
\hline
\end{tabular}

Instructions for use 


\title{
Larval morphology of Amphiops mater mater Sharp (Coleoptera: Hydrophilidae: Chaetarthriini)
}

\section{YÛSUKE MINOSHIMA ${ }^{1} \&$ MASAKAZU HAYASHI ${ }^{2}$}

${ }^{1}$ Systematic Entomology, Graduate School of Agriculture, Hokkaido University, Sapporo, 060-8589 Japan.E-mail: m-yusuke@ res.agr.hokudai.ac.jp

${ }^{2}$ Hoshizaki Green Foundation, Okinoshima 1659-5, Sono-chô, Izumo-shi, Shimane Pref., 691-0076 Japan. E-mail: hgf-haya@green-f.or.jp

\begin{abstract}
The larval morphology of Amphiops mater mater Sharp, 1873 is described, including chaetotaxy and morphological transformation between instars. Among genera of the family Hydrophilidae, the larvae of Amphiops Erichson, 1843 may be distinguished by the following combination of characters: coronal line present; clypeolabrum almost symmetrical; mandibles symmetrical and with three inner teeth; dorsal surface of palpomere 1 completely sclerotized; mentum with strongly projecting and sharply pointed anterior corners; ligula absent; spiracular atrium well developed. Several primary sensilla are absent from all instars of $A$. mater mater, in contrast to the stable chaetotaxy in the majority of Hydrophilidae species studied in detail to date.
\end{abstract}

Key words: aquatic beetles, water scavenger beetle, Hydrophilinae, immature stage, morphological transformation, chaetotaxy, Japan.

\section{Introduction}

Amphiops Erichson, 1843 is a small genus of the tribe Chaetarthriini (Hydrophilidae: Hydrophilinae) and is represented by 20 species from the Old World, including the Australian Region (Hansen 1991, 1999; Short \& Hebauer 2006; Short \& Fikáček 2011). Members of the genus generally inhabit lentic waters, including artificial ponds and paddy fields. Adults are easily recognized by their hemispherical body and compound eyes divided into dorsal and ventral portions. The general larval morphology of genus Amphiops has been described in several previous studies (e.g., Bertrand 1935, 1936, 1972; Yoshimura 1959; Marche-Marchad 1974; Berge Henegouwen 1982; Watts 2002; Hayashi 2009, 2011), however the larvae of only two species, A. queenslandicus Balfour-Browne, 1939 (Watts 2002) and A. mater mater Sharp, 1873 (Hayashi 2009, 2011) have been precisely identified; the remaining descriptions were based on unassociated material. Furthermore, the chaetotaxy of the genus has never been described.

In Japan, the only representative of the genus, A. mater mater, has been recorded throughout the country, excluding Hokkaidô. The immature stages of this species have been only superficially studied: Hosoi (1952) observed the behavior of egg-case construction and described the egg-case; Yoshimura (1959) described the larva of the species as 'Hydrophilus sp.', and Hayashi $(2009,2011)$ described briefly the larva and egg-case. In this paper, we describe larvae of A. mater in detail, including chaetotaxy and morphological transformation between instars, based on Japanese specimens.

\section{Material and methods}


General methods follow Minoshima and Hayashi (2011a). The examined specimens are deposited in the authors' collections and in National Museum, Prague, Czech Republic (M. Fikáček). Larvae were preserved in screw-cap vials with $80 \%$ ethanol or were mounted on HS-slides (Higgins-Shirayama slide; Shirayama et al. 1993) (Kanto Rika Co., Ltd., Japan) with Euparal (Chroma-Gesellschaft, Schmid \& Co., Germany). Composite images were created using the focus stacking software CombineZP (Hadley 2010). Morphological terminology generally follows Archangelsky (1997) and Minoshima and Hayashi (2011a) with the exception of the antennal segments, for which we followed Beutel (1999) and Fikáček et al. (2008); for the chaetotaxy of larval head we referred to Fikáček et al. (2008) and Byttebier and Torres (2009).

Abbreviation are used as follows: AN: antenna; E: egg-case; FR: frontale; gAN: group of antennal sensilla; gAPP: group of sensilla on inner appendage of maxilla; gFR: group of sensilla on frontale; gLA: group of sensilla on labium; gMX: group of sensilla on maxilla; L1, L2, L3: first, second and third larval instars; L?: larval instar unknown; LA: labium; MN: mandible; MX: maxilla; PA: parietale; SE: sensorium.

\section{Results}

\section{Description of larva}

\section{Amphiops mater mater Sharp, 1873}

(Figs. 1-8)

Material examined. All specimens were collected or collected and reared by M. Hayashi. JAPAN: Shimane Prefecture: 1 L2, 1 L3, Honshôji, Kozakai-chô, Izumo-shi (pond), 14.vi.2008 (date of fixation); 1 L3, Okinoshima, Sono-chô, Izumo-shi, 23.vii.2008; 1 L3, Okinoshima, Sono-chô, Izumo-shi, 25.vii.2008 (date of fixation); 3 L1, 1 L2, 1 L3, same data but, 22.vii.2009; 1 L3, same data but, 3.viii.2008 (date of fixation); 15 L1, Wadakami, Okuuga-chô, Izumo-shi (pond), 11.vi.2008 (date of fixation); 12 L1, same data but, 14.vi.2008 (date of fixation); $2 \mathrm{E}, 7 \mathrm{~L}$, 2 L2, same data but, 16.vi.2008 (date of fixation); $1 \mathrm{~L} 2$, same data but, 20.vi.2008 (date of fixation); 1 L1, 2 L3, same data but, 25.vi.2008 (date of fixation); $1 \mathrm{~L} 2$, same data but, 18.vii. 2008 (date of fixation); $2 \mathrm{~L} 1,1 \mathrm{~L} 2$, same data but, 21.vii.2008 (date of fixation); $10 \mathrm{~L} 1$, same data but, 25.vii.2008 (date of fixation); $1 \mathrm{~L} 1$, same data but, 30.vii.2008 (date of fixation); $1 \mathrm{~L} 2,1 \mathrm{~L} 3$, same data but, 10.viii.2008 (date of fixation); 1 L3, Sadamiyauchi, Kashima-chô, Matsue-shi, 11.ix.2006.

Diagnosis. Dorsal surface of head capsule smooth; coronal line present, rather long (Fig. 5A). Clypeolabrum almost symmetrical; nasale with five large teeth medially and two to three small teeth laterally (Figs. 2D-E, 6C). Mandibles symmetrical, with three inner teeth, distal two large and bearing small subapical tooth on anterior edge; basal one very small (Figs. 3B-C, 7B-C). Dorsal surface of palpomere 1 completely sclerotized (Figs. 3D, 7D). Labium without well developed hypopharyngeal lobe; mentum oblong subrectangular with strongly projecting and sharply pointed anterior corners; prementum small; ligula absent (Figs. 3F-H, 7F-H). Legs well developed, visible in dorsal view (Figs. 1, 4B-C). Abdomen without spinose prolegs; dorsal plate of spiracular atrium with four lobes posteriorly; acrocerci short, stout, truncate apically (Fig. 5C).

Description. General morphology. Third instar. Body (Fig. 1C) somewhat slender, widest between metathorax and third abdominal segment. Nine pairs of spiracles, one pair on mesothorax and eight pairs on abdominal segments 1 to 8; mesothoracic and first seven pairs of abdominal spiracles non-functional, biforous; last pair annular, large and functional, 
enclosed within the spiracular atrium.

Color (Fig. 1C). Head yellowish brown; thorax and abdomen light yellowish brown dorsally, infuscate yellowish white ventrally. Dorsal surface of head, pronotum and mesoand metathoracic terga with sparsely arranged small dark spots. Abdominal segments bicolored; median part darker than lateral part; dorsal sclerites and dorsal plate on abdominal segment 8 dark brown to brown, dorsal plate with two longitudinal dark lines medially.

Head (Figs. 5A, 6). Head capsule subquadrate, slightly wider anteriorly; cervical sclerites subquadrate, wider than long. Surface of head capsule smooth. Frontal lines clearly visible only posterior half, almost V-shaped, fused at posterior part of head capsule; coronal line present, rather long. Six stemmata closely aggregated, on each anterolateral corner of head capsule. Clypeolabrum almost symmetrical. Nasale with five large teeth and two to three small teeth, smaller ones located laterally to large ones. Epistomal lobe broadly rounded, projecting as far as nasale or nearly so.

Antenna (Fig. 7A) 3-segmented, slender; antennomere 1 about as long as antennomere 2 ; antennomere 2 bearing a few very small cuticular spines on inner part of ventral surface; antennomere 3 distinctly shortest and narrowest.

Mandibles (Figs. 7B-C) symmetrical, with three inner teeth; distal two large, bearing small subapical tooth on distal margin; basal one very small.

Maxilla (Figs. 7D-E) 6-segmented; longer than antenna. Cardo very small, irregularly triangular. Stipes long, bearing a few cuticular spines; a few small cuticular spines on inner face, one on subapical, remaining ones basally between setae MX7 and MX8; two to three cuticular spines on outer face, the number of spines shows variation, sometimes absent or sometimes bearing more. Maxillary palpus 4-segmented. Palpomere 1 the widest, distinctly shorter than palpomere 3 ; dorsal surface of palpomere 1 completely sclerotized; inner process sclerotized; palpomere 2 very short, with two small cuticular spines on dorsolateral face of intersegmental membrane between palpomeres 2 and 3; palpomere 3 the longest, slender; palpomere 3 the narrowest, rather small.

Labium (Figs. 7F-H) well developed, rather small. Submentum large, subpentagonal, wider than mentum. Mentum oblong subrectangular with strongly projecting and sharply pointed anterior corners, wider than long; dorsal surface bearing strong cuticular teeth anteriorly, laterally and posterolaterally. Prementum small, rectangular, wider than long, much narrower than mentum. Ligula absent. Labial palpus short; palpomere 1 very short, palpomere 2 distinctly longer than palpomere 1 .

Thorax. Sclerites covered with densely arranged, fine cuticular spines (Fig. 8A); dorsal surface of membranous parts strongly to finely rugose (e.g., Fig. 8B); ventral surface of membranous parts covered with fine, hair-like cuticular spines. Prothorax wider than head capsule. Pronotum formed by one large plate subdivided by fine sagittal line and sparsely covered with setae of variable length, anterior and posterior portions weakly sclerotized. Prosternum (Fig. 5B) subpentagonal, with very short, fine sagittal line, bearing densely arranged setae on anterior part. Meso- and metathorax with several sized tubercles bearing very small but strong cuticular spines and long setae laterally; mesonotum with one large plate subdivided by fine sagittal line and a transverse ridge on anterior part; each anterior corner with one small sclerite. Metanotum with one large plate on anterior part; the plate subdivided by fine sagittal line and a transverse ridge. Meso- and metasternum with one setiferous tubercle bearing long setae on each side, laterally to coxal cavity.

Legs (Fig. 4C) well developed, rather short but visible in dorsal view, 5-segmented, all three pairs similar in shape; coxa bearing densely arranged long to very long setae anterodorsally; trochanter and femur bearing densely arranged rather short to very long setae ventrally and anteroventrally; tibiotarsus with several rather long setae.

Abdomen. Abdomen 10-segmented, mostly membranous, tapering towards posteriad 
(Fig. 1C); dorsal sclerites bearing small cuticular spines; dorsal surface of membranous part strongly rugose (Fig. 8B); ventral surface of membranous parts covered with densely arranged, fine hair-like cuticular spines; tubercles on abdominal segments bearing very small but strong cuticular spines and setae of variable length, lateral tubercles bearing long setae. Segments 1 to 7 similar in shape and size, each with one pair of small dorsal sclerites anteromedially, two pairs of median tubercles bearing rather long setae, and one pair of posterolateral tubercles bearing short setae; dorsal sclerites on segment 1 larger than those on segments 2 to 7; lateral sides of abdominal segments moderately projected (Fig. 1C) and bearing long setae on tubercles.

Spiracular atrium (Fig. 5C): Segment 8 with oval dorsal plate covered with fine hairlike cuticular spines on median and lateral parts; posterior edge of segment 8 with four projections covered with fine hair-like cuticular spines, median two projections larger than lateral ones, weakly emarginate medially, projections attached to the posterior margin of dorsal plate slightly below level of the plate; procercus mostly sclerotized, bearing one rather long and two short setae; segment 9 trilobed, partially sclerotized; acrocerci short, stout, truncate apically; urogomphi short, one segmented, with one very long seta on apical membranous part; prostyli reduced.

Second instar. Similar to third instar larva.

Head. Frontal lines clearly visible, nearly bell-shaped (e.g., Fig. 2A).

Antenna (Fig. 4A) proportionally shorter and stouter than in third instar, antennomere 1 shorter than antennomere 2 .

Labium: Shape of mentum nearly first instar (Fig. 3F-H), slightly more roundish in outline than in third instar instar.

First instar. Similar to second instar larva, more weakly sclerotized than third instar. Dorsal surface of membranous parts moderately rugose (e.g., Fig. 8B), covered with densely arranged, fine hair-like cuticular spines; lateral and ventral surfaces of membranous parts covered with densely arranged, fine hair-like cuticular spines, the spines longer and denser than those on dorsal surface.

Head (Fig. 2). Epistomal lobe not projecting further than nasale.

Antenna (Fig. 3A) proportionally shorter and stouter than those of second and third instars; antennomere 1 distinctly shorter than antennomere 2; antennomere 2 slightly narrower than antennomere 1.

Maxilla (Figs. 3D-E) proportionally stouter than in second and third instars.

Labium (Figs. 3F-H): Mentum more roundish in outline than in second and third instars.

Thorax. Setation of legs sparser than in second instar (Fig. 4B).

Primary chaetotaxy of larval head. Frontale altogether with 50 sensilla (Figs. 2A, DE). Central part with three pairs of sensilla divergent posteriad (FR1-3); FR1 short seta close to frontal line; FR2 pore-like between FR1 and FR3; FR3 very short seta, situated more anteriorly and mesally than FR1 and FR2. Two setae (FR5 and FR6) and pore-like sensillum (FR4) situated posteromesally to antennal socket, FR5 and FR6 close to frontal line; FR5 short, posterolaterally to FR4, at midlength of line connecting frontal line and FR4; FR6 rather long, close to antennal socket. Seta FR7 rather long, close to inner margin of antennal socket. Nasale with group of six equidistant, stout and short setae, two very short setae and four small pore-like sensilla (gFR1) (Fig. 2E); lateral-most seta on each side situated in emargination between nasale and epistomal lobe; one pair of pore-like sensilla on inner margin of each lateral-most large tooth, one pair of pore-like sensilla and one pair of short setae close and laterally to median two setae. Anterior margin of each epistomal lobe with a group of three very short setae and one small pore-like sensillum (gFR2), lateral-most seta longer than remaining setae. Pore-like sensillum FR15 situated posteriorly to median setae of nasale; rather long seta FR8 posterolaterally to FR15. FR9 rather long seta between antennal 
socket and FR8; long seta FR10 and pore-like sensillum FR14 located anterolaterally to antennal socket, FR14 more laterally than FR10. Epistomal lobe with three sensilla (FR1113), FR11 and FR13 pore-like, FR12 short and stout seta; FR11 situated laterally and close to lateral-most seta of gFR1; FR12 posteriorly and close to gFR2; FR13 situated posteriorly and slightly mesally to FR 12 .

Parietale with 30 sensilla each (Figs. 2A-C). Dorsal surface with a group of five sensilla (PA1-5) situated posteriorly forming a longitudinal row at midwidth; PA3 pore-like, between PA2 and PA4; remaining sensilla short; location of PA1-5 variable (Figs. 2A, C). PA6 pore-like, situated posterolaterally to joint of frontal and coronal lines, more distant from posterior margin of head than PA1. Setae PA7 and PA8 long, close to frontal line; PA7 situated posteromesally to PA8, equidistant from PA8 and PA12; seta PA12 long, at midlength between PA5 and PA8. Seta PA9 very long, close to outer margin of antennal socket. PA10 pore-like, situated laterally to PA8, between PA8 and PA11 but more closer to PA8 than PA11; rather long seta PA11 on dorsolateral surface, situated posterolaterally to PA9. Two long setae (PA13 and PA14) located dorsolaterally on anterior third of parietale, posteriorly to PA11; PA13 longer than PA14; PA14 posterolaterally to PA13. Anterior corner of epicranium with one pore-like sensillum (PA19) and three setae (PA20-22); PA19 situated dorsally to the latter setae; PA20 long, between PA19 and PA21; PA21 very long, between PA20 and PA22; PA22 very long, situated ventrally to the remaining sensilla (PA19-PA21). Two pore-like sensilla (PA15 and PA17) and two very long setae (PA16 and PA18) situated laterally on anterior third of parietale; PA15 dorsally to remaining sensilla; PA17 ventrally to remaining sensilla; PA16 shorter than PA18, anteriorly to remaining sensilla, PA18 posteriorly to remaining sensilla. Three pore-like sensilla (PA23-25) on anterior margin close to ventral mandibular acetabulum; PA23 more distant from PA24-25 than the latter from each other; PA23 close to PA22; PA24-25 situated laterally on ventral mandibular acetabulum; PA24 posterolaterally to PA25. Two very long setae (PA26 and PA28) and porelike sensillum (PA27) situated medially on ventral surface of parietale; PA26 anteriorly to PA27-28; PA27 between PA26 and PA28. PA29 and PA30 pore-like sensilla; PA29 situated posteromesally to PA28; PA30 on posterolateral part of ventral parietale, posterolaterally to PA29.

Antenna (Fig. 3A): Antennomere 1 with five pore-like sensilla (AN1-5); AN1 and AN2 situated dorsally; AN1 on basal 0.35, AN2 on distal 0.22; AN3-5 situated subdistally, AN3 on outer face, AN4 on inner face, AN5 on ventral surface. Antennomere 2 with one pore-like sensillum (AN6) situated dorsally on distal 0.45; four setae (AN7-8 and AN10-11) on subdistal part; AN7 and AN8 on dorsolateral face; AN7 very short and rather stout, situated posteriorly and close to SE1; AN8 minute, posteriorly to AN7; AN10 long on inner face, located ventrally and close to AN11; AN11 very short. SE1 long and narrow, slightly shorter than antennomere 3. Antennomere 3 with several apical setae (gAN) in apical membranous area; two long setae, two rather short and broadened setae, and remaining ones short.

Mandible (Figs. 3B-C) with 2 setae (MN1 and MN5) and 4 pore-like sensilla (MN2-4 and MN6). MN1 rather long, on basal third of outer face. MN2 and MN4 on dorsolateral face of mandible, close to MN1; MN4 located anteriorly to MN1; MN2 anteromesally to MN1; MN3 close to base of distal-most inner tooth. MN5 minute, situated subapically on outer face; MN6 small, very indistinct, situated subapically on inner face of mandible, more apically than MN5.

Maxilla (Figs. 3D-E): Cardo with one long seta ventrally (MX1). Stipes with a longitudinal row of five rather short, stout setae (MX7-11) situated dorsally along inner face; distance between MX7 and MX8 shorter than that between MX8-9; distance between MX10 and MX11 shorter than that between MX7 and MX8. Ventral surface of stipes with two porelike sensilla (MX2 and MX3); MX2 situated lateroventrally on basal third; MX3 close to 
inner face, on basal 0.44. One pore-like sensillum (MX4) and two setae (MX5-6) situated subapically on lateral face; MX4 posteriorly to MX5-6; MX5 long, mesally to MX6; MX6 very long. Palpomere 1 with one moderately long, trichoid seta (MX16) situated basally on inner face, and with one pore-like sensillum (MX12) and two moderately long setae (MX1314) along distal margin of sclerite; MX12 and MX13 located dorsolaterally, MX14 ventrally; MX12 more mesally than MX13. MX15 and MX17 presumably absent. Inner appendage with a few setae (gAPP) on apical membranous area; one long, narrow paddle-shaped seta, remaining ones short to rather short. Palpomere 2 with one pore-like sensillum (MX18) and one minute seta (MX27), MX19 absent; MX18 situated ventrally on borderline between sclerite and intersegmental membrane between palpomeres 2 and 3; MX27 located basally on lateral face. Palpomere 3 with two rather long setae (MX21 and MX23) and two pore-like sensilla (MX20 and MX22); MX20-21 and MX23 on distal margin of sclerite, MX22 on distal 0.22 of sclerite; MX20 and MX23 situated laterally, MX21 and MX22 ventrally; MX23 more dorsally than MX20; MX21 anteriorly to MX22. Palpomere 4 with one rather long seta (MX24) situated basally on inner face, and with digitiform sensillum (MX25) and pore-like sensillum (MX26) situated subapically on outer face, MX25 dorsally to MX26. Apical membranous area of palpomere 4 with several short setae (gMX).

Labium (Figs. 3F-H): Submentum with two pairs of setae (LA1-2); LA1 very long on lateral corners, LA2 short on anterolateral corners. Mentum with 2 pairs of sensilla ventrally; moderately long seta (LA3) on basal 0.35 , situated posteriorly and slightly laterally to LA4; pore-like sensillum LA4 on distal 0.47. Dorsal surface of prementum with a pair of pore-like sensilla (LA8) situated medially on anterior margin of sclerite. Ventral surface of prementum with three pairs of sensilla; seta LA5 short situated basally on lateroventral face; seta LA6 very long, between LA7 and LA5 but mesally of line connecting LA5 and LA7; LA7 porelike lateroventrally on distal margin of sclerite. Membrane between prementum and palpi with two pair of pore-like but slightly digitiform sensilla (LA9 and LA12) and one pair of very long seta (LA10); LA9 situated posteriorly to LA12; LA10 laterally to LA9 and LA12. LA11 absent. Labial palpomere 1 with one minute seta (LA13) situated ventrally on its base, close to lateral face. LA14 and LA15 absent. Apical membranous area with several long to rather short setae (gLA).

Chaetotaxy of larval head. Second and third instars. Chaetotaxy of second and third instars very similar except for antennal sensorium SE1.

Frontale (Figs. 6A, C): One rather long secondary seta situated posteriorly to FR8.

Parietale (Figs. 6A-B): Very small secondary pore-like sensillum close to PA1. One moderately short seta located posteriorly to PA7, close to frontal line, laterally to line connecting PA6 and PA7. One rather long secondary seta on anterior part of lateroventral surface of parietale between PA17 and PA23.

Antenna (Figs. 4A, 7A): AN1 on basal 0.35, AN2 on apical 0.31. AN6 on distal 0.51. One very small pore-like secondary sensillum on median part of outer face of antennomere 2, sometimes absent (Fig. 4A). SE1 of second instar proportionally shorter than that of first instar (Fig. 4A), that of third instar proportionally shorter than that of second instar (Fig. 7A).

Mandible (Figs. 7B-C): Outer face of mandible with two secondary sensilla; one porelike secondary sensillum on basal part; one rather long seta situated posteriorly to MN1, at midlength between MN1 and pore-like secondary sensillum. MN6 undetectable.

Maxilla (Figs. 7D-E): Stipes with three long secondary setae; one on ventral surface, close to MX3; one on median part of outer face; one on subapical part of outer face, close to MX5-6, undetectable from primary sensilla (MX5-6).

Labium (Figs. 7G-H): One rather long secondary seta on anterior corner of ventral surface of mentum.

Habitat. Standing water: larvae were found together with adults. This species prefers 
ponds rather than paddy fields in Shimane Prefecture.

Identification. Some of the specimens were reared from egg-cases laid by identified adults by the second author. Remaining specimens were collected in the field and compared with those that were reared. As no other species of Amphiops is known to occur in Japan, all specimens collected in the field can confidently be assigned to this species.

Bibliography. Hosoi (1952) (E; observation of the behavior of egg-case construction and description of egg-case, as Amphiops gibbus mater Sharp, Fig. 4); Yoshimura (1959) (L?; description, as Hydrophilus sp; see below); Hayashi (2008) (L?; photo, as unknown hydrophilid larva, Fig. 22K); Hayashi (2009, 2011) (E, L3; diagnosis, photo and figures).

Yoshimura (1959) described an undetermined Japanese hydrophilid larva collected in the field as Hydrophilus sp. Judging from the description, figures and the locality where the specimens were collected (Nara Prefecture, Japan), the larvae described by him belong to $A$. mater.

\section{Discussion}

The larvae of the genus Amphiops are distinguished from those of other known chaetarthriines (Chaetarthria Stephens, 1835 and Guyanobius Spangler, 1986) by the following combination of characters: presence of coronal line (coronal line is absent in the Chaetarthria and Guyanobius), the presence of well developed legs (reduced in Chaetarthria), and the absence of ligula (present in Guyanobius) (Spangler 1986; Archangelsky 1997, 2002b; Watts 2002).

The chaetotaxy of hydrophilid larvae has been considered to be stable in the majority of the species studied in detail (Fikáček et al. 2008). Despite that, several primary sensilla on the head appendages of Amphiops mater are absent in all instars: antenna (AN9) (Figs. 3A, 4A, 7A), maxilla (MX15, MX17 and MX19) (Figs. 3D-E, 7D-E) and labium (LA11, LA14 and LA15) (Figs. 3F-H, 7F-H). In addition, the proportional size of the antennal sensorium SE1 gradually decreases according to their larval growth (Figs. 3A, 4A, 7A). This trend of the proportional size of the SE1 has also been observed in the genus Enochrus (Hydrophilinae, Acidocerini) (Archangelsky 2002a; Minoshima \& Hayashi 2011a).

Reduction of the sensilla adjacent SE1 occurs independently in several taxa of Hydrophilidae (Fikáček et al. 2008; Minoshima \& Hayashi 2011a; Torres et al. 2011) and it seems to be common in Hydrophilidae chaetotaxy. However, there is no key evidence to define homology of the sensilla adjacent to SE1, and therefore we consider that the smallest sensilla is absent; AN9 is generally the smallest sensilla or is absent in antennal chaetotaxy of Hydrophilidae (Fikáček et al. 2008; Minoshima \& Hayashi 2011a, b; Torres et al. 2011).

The presence of primary sensilla on the maxilla is very stable in most Hydrophilidae species that have been described so far (Fikáček et al. 2008; Byttebier \& Torres 2009; Minoshima \& Hayashi 2011a, b; Torres et al. 2011). MX15 and MX17 are undetectable, hence we consider that these sensilla on A. mater are absent. Absence of MX15 and MX17 is also noted in Cercyon convexiusculus Stephens, 1829 (Sphaeridiinae, Megasternini) (Fikáček et al. 2008).

The absence of some sensilla on the labium is probably due to a reduction of the labial structure (Figs. 3F-H, 7F-H). The trend of reduction of sensilla on labium is known in several Hydrophilidae which have modified labial structures (Fikáček et al. 2008).

In conclusion, the absence of the sensilla on the antenna and labium seems to follow some known trends of hydrophilid chaetotaxy. On the other hand, the absence of MX19 is unique to Amphiops and has not been reported from other Hydrophilidae species of which the chaetotaxy has been studied in detail. 


\section{Acknowledgements}

We thank Masahiro Ôhara (Systematic Entomology, Hokkaido University, Sapporo, Japan), Martin Fikáček (National Museum, Prague, Czech Republic) and Hiroyuki Yoshitomi (Ehime University Museum, Matsuyama, Japan) for their cordial advice and valuable comments on the manuscript; Miguel Archangelsky (CONICET-LIESA, Universidad Nacional de la Patagonia San Juan Bosco, Esquel, Argentine Republic) for his kind advice and constructive criticisms to the manuscript. This study was partly supported by Grant-in-Aid for JSPS Fellows (10J03421) to the first author.

\section{References}

Archangelsky, M. (1997) Studies on the biology, ecology, and systematics of the immature stages of New World Hydrophiloidea (Coleoptera: Staphyliniformia). Bulletin of the Ohio Biological Survey, New Series, 12, 1-207.

Archangelsky, M. (2002a) Immature stages of Neotropical Enochrus (Coleoptera: Hydrophilidae): E. (Methydrus) lampros Knisch, 1924 and E. (Hugoscottia) tremolerasi Knisch, 1922. Aquatic Insects, 24 (1), 41-52.

Archangelsky, M. (2002b) Nuevas larvas de Hydrophilidae (Coleoptera: Hydrophiloidea): Hemiosus multimaculatus y Chaetarthria bruchi. Revista de la Sociedad Entomologica Argentina, 61, 89-97.

Balfour-Browne, J. (1939) Contribution to the study of the Palpicornia part III. Annals and Magazine of Natural History, Including Zoology, Botany and Geology. Eleventh Series, 4, 289-310.

Berge Henegouwen, A.L., van. (1982) Notes on the larval stages of some East African Hydrophilinae (Coleoptera: Hydrophilidae). Entomologische Berichten, 42, 11-16.

Bertrand, H. (1935) Voyage de Ch. Alluaud et de P. A. Chappuis dans l'Afrique occidentale francaise. Larves se Coléopteres aquatiques. Revue française d'entomologie, 2 (3), 132 140.

Bertrand, H. (1936) Larves de Coléopteres aquatiques de l'Expédition Limnologique Allemande en Insulinde. Archiv für Hydrobiologie, Supplement Band XIV "Tropische Binnengewässer, Band VI", 6, 193-285, pls. I-XI.

Bertrand, H. (1972) Larves et Nymphes des Coléoptères Aquatiques du Globe. Imprimerie F. Paillart, Abbeville, 804 pp.

Beutel, R.G. (1999) Morphology and evolution of the larval head of Hydrophiloidea and Histeroidea (Coleoptera: Staphyliniformia). Tijdschrift voor Entomologie, 142, 9-30.

Byttebier, B. \& Torres, P.L.M. (2009) Description of the preimaginal stages of Enochrus (Hugoscottia) variegatus (Steinheil, 1869) and E. (Methydrus) vulgaris (Steinheil, 1869) (Coleoptera: Hydrophilidae), with emphasis on larval morphometry and chaetotaxy. Zootaxa, 2139, 1-22.

Fikáček, M., Archangelsky, M. \& Torres, P.L.M. (2008) Primary chaetotaxy of the larval head capsule and head appendages of the Hydrophilidae (Coleoptera) based on larva of Hydrobius fuscipes (Linnaeus, 1758). Zootaxa, 1874, 16-34.

Hadley, A. (2010) CombineZP. Available online at http://www.hadleyweb.pwp.blueyonder.co.uk/.

Hansen, M. (1991) The hydrophiloid beetles. Phylogeny, classification, and a revision of the genera (Coleoptera: Hydrophiloidea). Biologiske Skrifter, 40, 1-367. 
Hansen, M. (1999) World Catalogue of Insects 2: Hydrophiloidea (s. str.) (Coleoptera). Apollo Books, Amsterdam, 416 pp.

Hayashi, M. (2008) Distributional records and ecological notes on aquatic Coleoptera of Shimane prefecture, Part II. Bulletin of Hoshizaki Green Foundation (11), 61-91. (In Japanese with English title and abstract)

Hayashi, M. (2009) Aquatic Hydrophilidae of Shimane prefecture. Bulletin of Hoshizaki Green Foundation (12), 87-121. (In Japanese with English title and abstract)

Hayashi, M. (2011) Aquatic Coleoptera of Shimane Prefecture. Special Bulletin of the Hoshizaki Green Foundation (1), 1-117. (In Japanse with English title)

Hosoi, M. (1952) [Observations of the behavior of egg cases laying in the family Hydrophilidae]. Kagaku Kyôiku News (29), 4-6. (In Japanese)

Marche-Marchad, J. (1974) Observation sur la biologie des Amphiops Er. (Coleopteres Hydrophilidae): decouverte de la nymphe. Bulletin de l'Institut Fondamental d'Afrique Noire. Série A, Sciences Naturelles, 36 (4), 924-930.

Minoshima, Y. \& Hayashi, M. (2011a) Larval morphology of the Japanese species of the tribes Acidocerini, Hydrobiusini and Hydrophilini (Coleoptera: Hydrophilidae). Acta Entomologica Musei Nationalis Pragae, 51 (supplementum), 1-118.

Minoshima, Y. \& Hayashi, M. (2011b) Larval morphology of the genus Hydrocassis Fairmaire (Coleoptera: Hydrophilidae). Journal of Natural History, 45 (45-46), 27572784.

Sharp, D. (1873) The water beetles of Japan. Transactions of the Entomological Society of London, 1873, 45-67.

Shirayama, Y., Kaku, T. \& Higgins, R.P. (1993) Double-sided microscopic observation of meiofauna using an HS-slide. Benthos Research (44), 41-44. (In Japanese with English title and abstract)

Short, A.E.Z. \& Fikáček, M. (2011) World catalogue of the Hydrophiloidea (Coleoptera): additions and corrections II (2006-2010). Acta Entomologica Musei Nationalis Pragae, $51(1), 83-122$.

Short, A.E.Z. \& Hebauer, F. (2006) World catalogue of Hydrophiloidea - additions and corrections, 1 (1999-2005) (Coleoptera). Koleopterologische Rundschau, 76, 315-359.

Spangler, P.J. (1986) A new genus and species of water scavenger beetle, Guyanobius adocetus, from Guyana and its larva (Coleoptera, Hydrophilidae, Hydrobiinae). Proceedings of the Entomological Society of Washington, 88 (3), 585-594.

Stephens, J.F. (1829 (1828-29)) Illustrations of British Entomology; or, A Synopsis of Indigenous Insects: Containing Their Generic and Specific Distinctions. Mandibulata. Vol. II. Baldwin and Cradock, London, 200 pp + pls. 10-15. (Only 113-200 pp. and pls. 13-15 issued in 1829)

Torres, P.L.M., Michat, M.C. \& Archangelsky, M. (2011) The immature stages of Tropisternus (Pleurhomus) sahlbergi (Sharp) (Coleoptera: Hydrophilidae), with considerations on the primary chaetotaxy of Tropisternus Solier. Zootaxa, 2777, 25-40.

Watts, C.H.S. (2002) The larvae of some Australian aquatic Hydrophilidae (Coleoptera: Insecta). Records of the South Australian Museum, 35 (2), 105-138.

Yoshimura, A. (1959) [Descriptions of two hydrophilid larvae from Japan (Coleoptera)]. Kansai Shizen Kagaku Kenkyû-kai Kaishi (12), 28-29. (In Japanese) 


\section{Figure captions}

FIGURE 1. Habitus of the larvae of Amphiops mater mater Sharp, 1873. A, first instar, dorsal view; $\mathrm{B}$, second instar, dorsal view; $\mathrm{C}$, third instar, dorsal, lateral and ventral views.

FIGURE 2. Head capsule of Amphiops mater mater Sharp, 1873, first instar. A, dorsal view; $\mathrm{B}$, ventral view; $\mathrm{C}$, intraspecific variation of location of PA1-5; D, detail of anterior margin of head capsule, dorsal view; E, detail of nasal, dorsal view.

FIGURE 3. Head appendages of Amphiops mater mater Sharp, 1873, first instar. A, antenna, dorsal view; B-C, mandibles, dorsal view; D, maxilla, dorsal view; E, maxilla, ventral view; F, labium, dorsal view; $\mathrm{G}$, detail of prementum, dorsal view; $\mathrm{H}$, labium, ventral view.

FIGURE 4. Amphiops mater mater Sharp, 1873. A, antenna, second instar, dorsal view; B-C, mesothoracic legs, anterior view, B, first instar, C, third instar.

FIGURE 5. Amphiops mater mater Sharp, 1873. A, head, dorsal view; B, prosternum, ventral view; $\mathrm{C}$, spiracular atrium, dorsal view.

FIGURE 6. Head capsule of Amphiops mater mater Sharp, 1873, third instar. A, dorsal view; $\mathrm{B}$, ventral view; $\mathrm{C}$, detail of anterior margin of head capsule, dorsal view.

FIGURE 7. Head appendages of Amphiops mater mater Sharp, 1873, third instar. A, antenna, dorsal view; B-C, mandibles, dorsal view; D, maxilla, dorsal view; E, maxilla, ventral view; F, labium, dorsal view; $\mathrm{G}$, detail of prementum, dorsal view; $\mathrm{H}$, labium, ventral view.

FIGURE 8. Amphiops mater mater Sharp, 1873, third instar. A, surface of proscutum; B, dorsal surface of abdomen. 

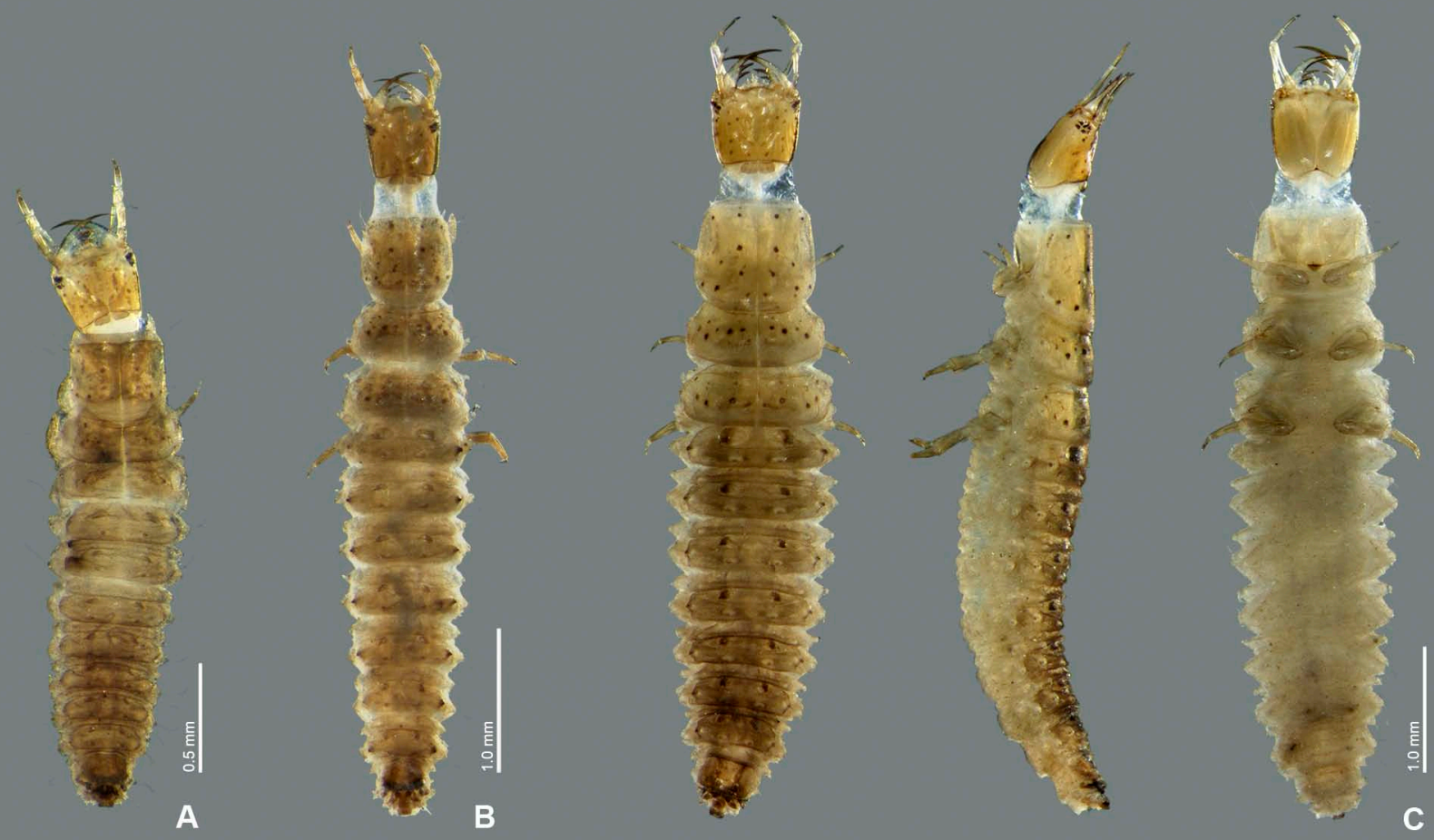

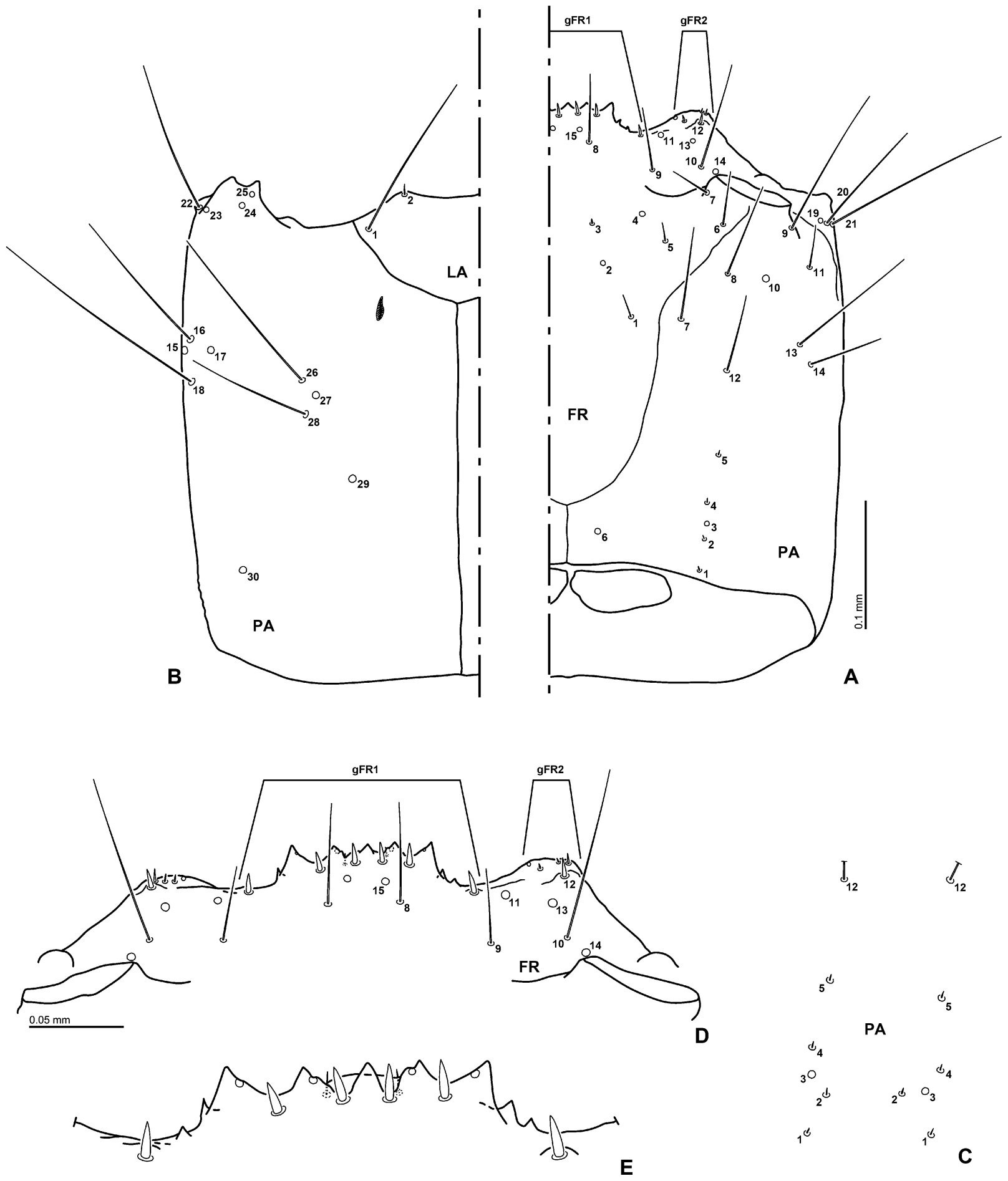


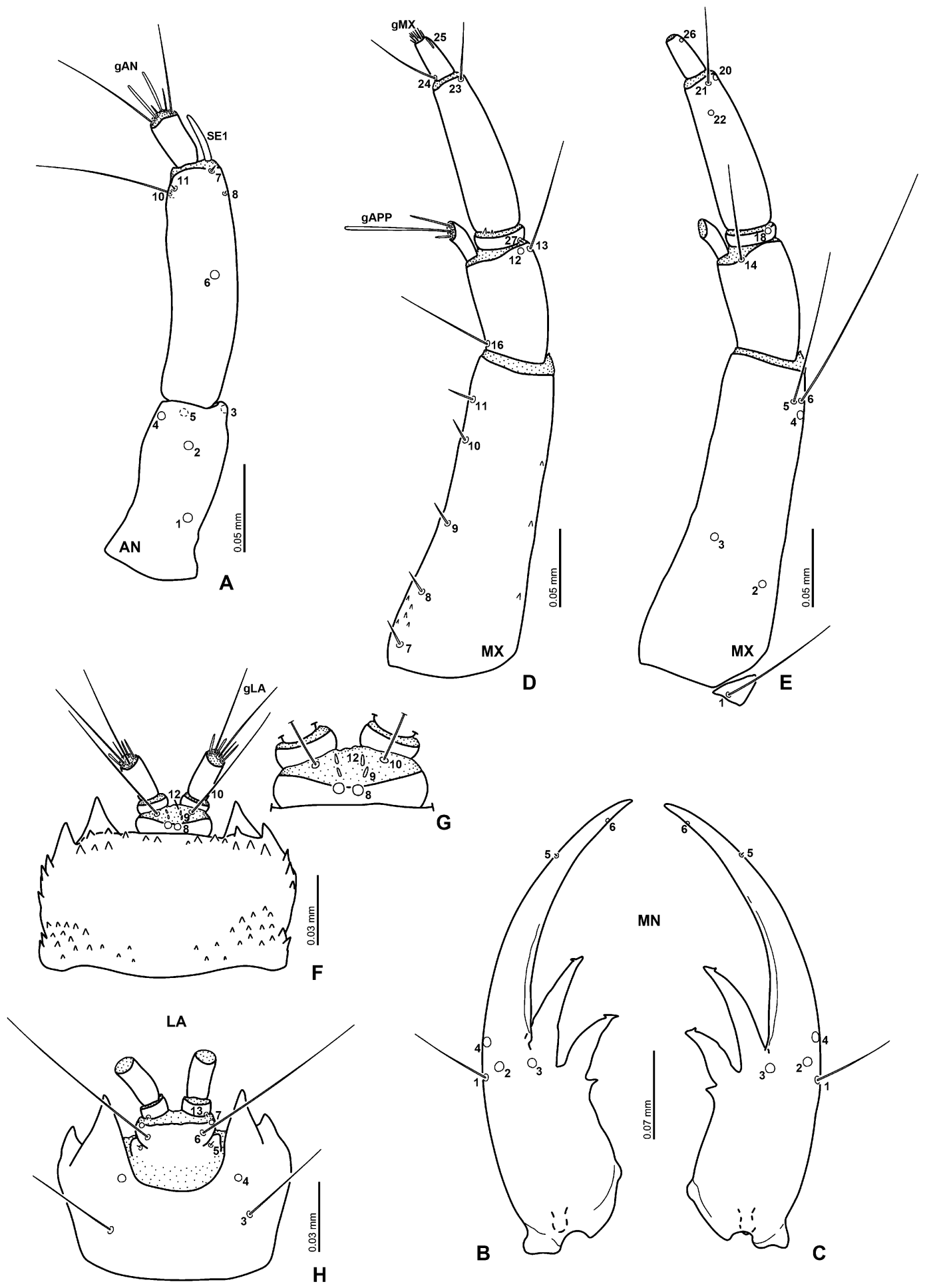




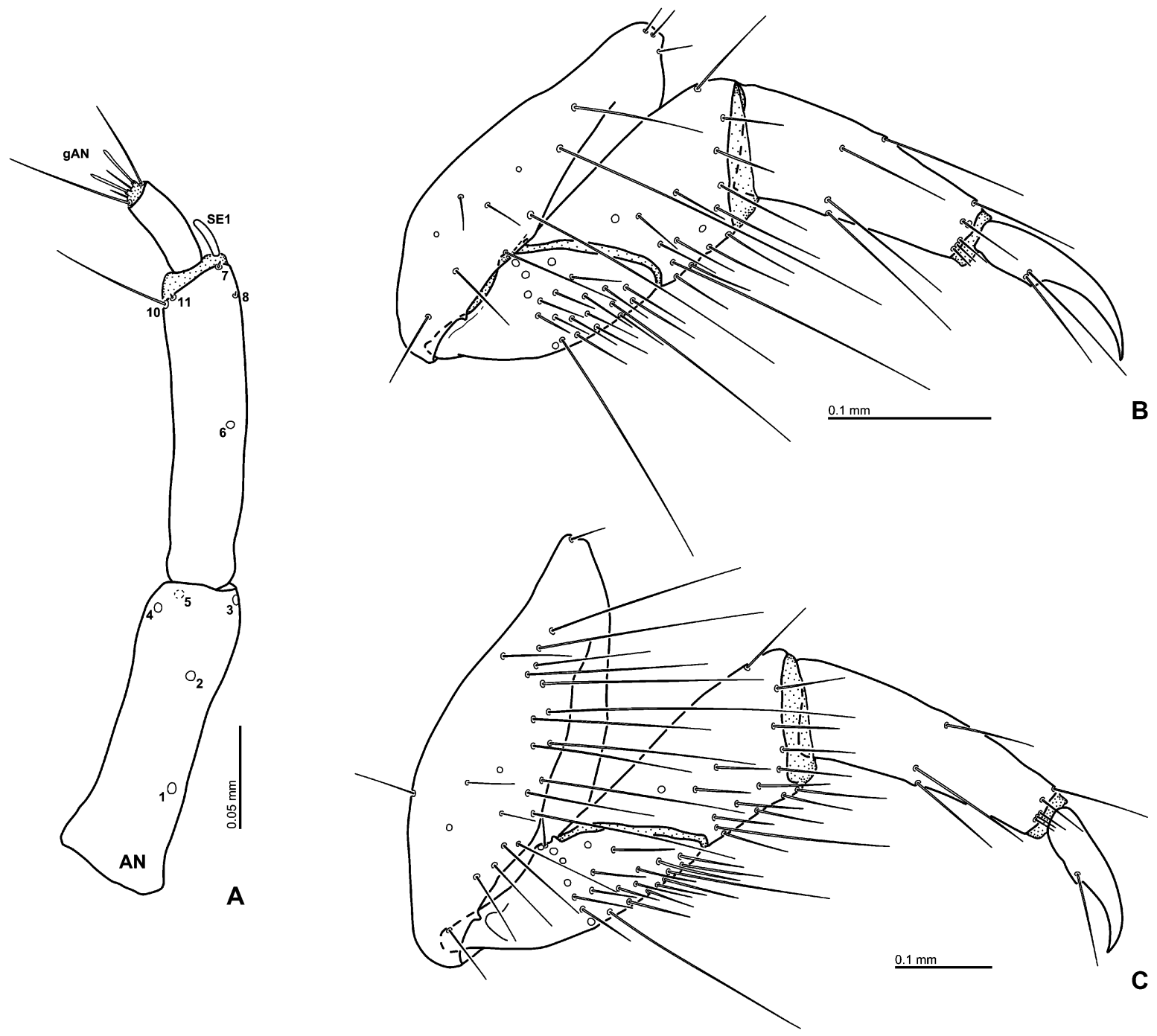




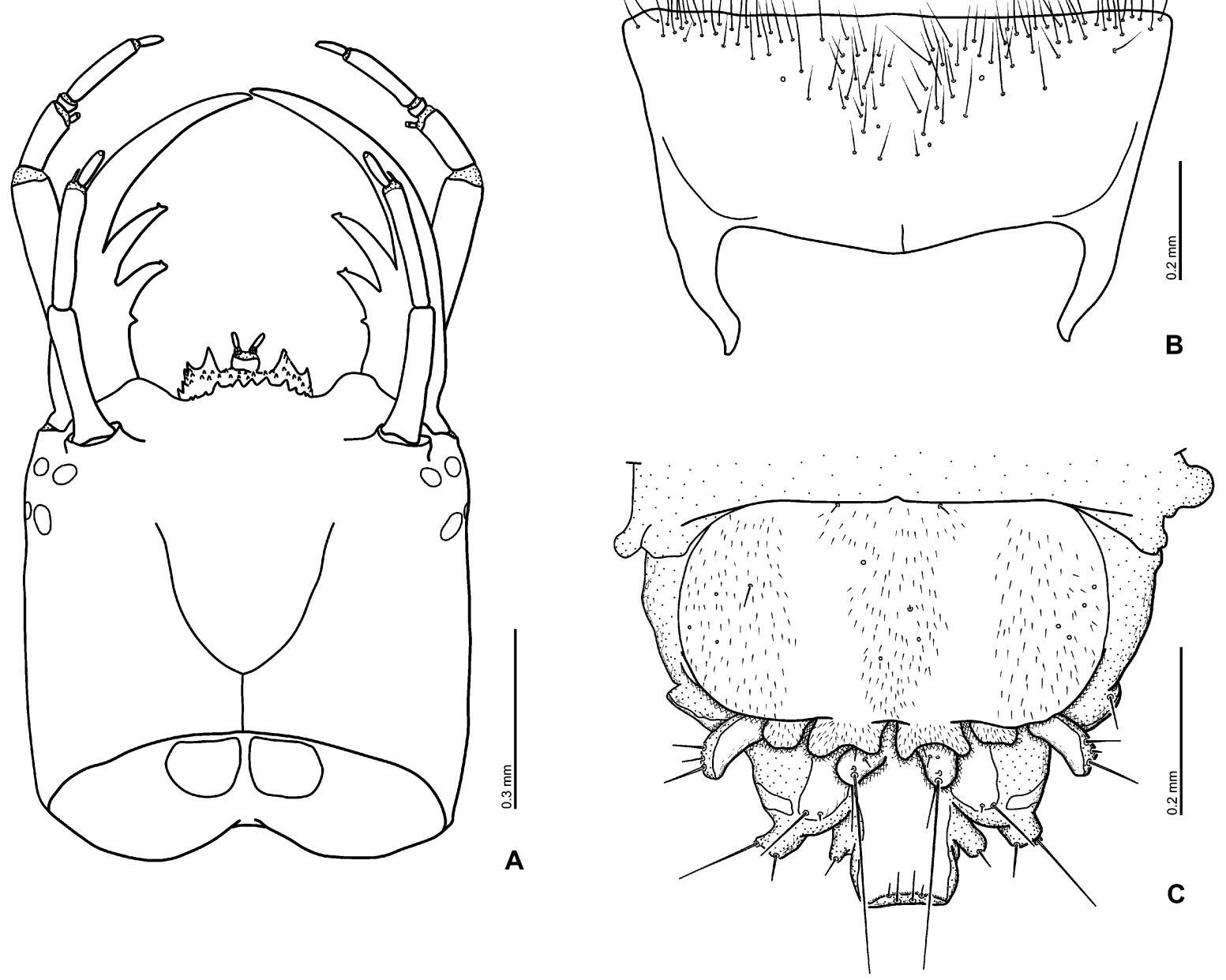



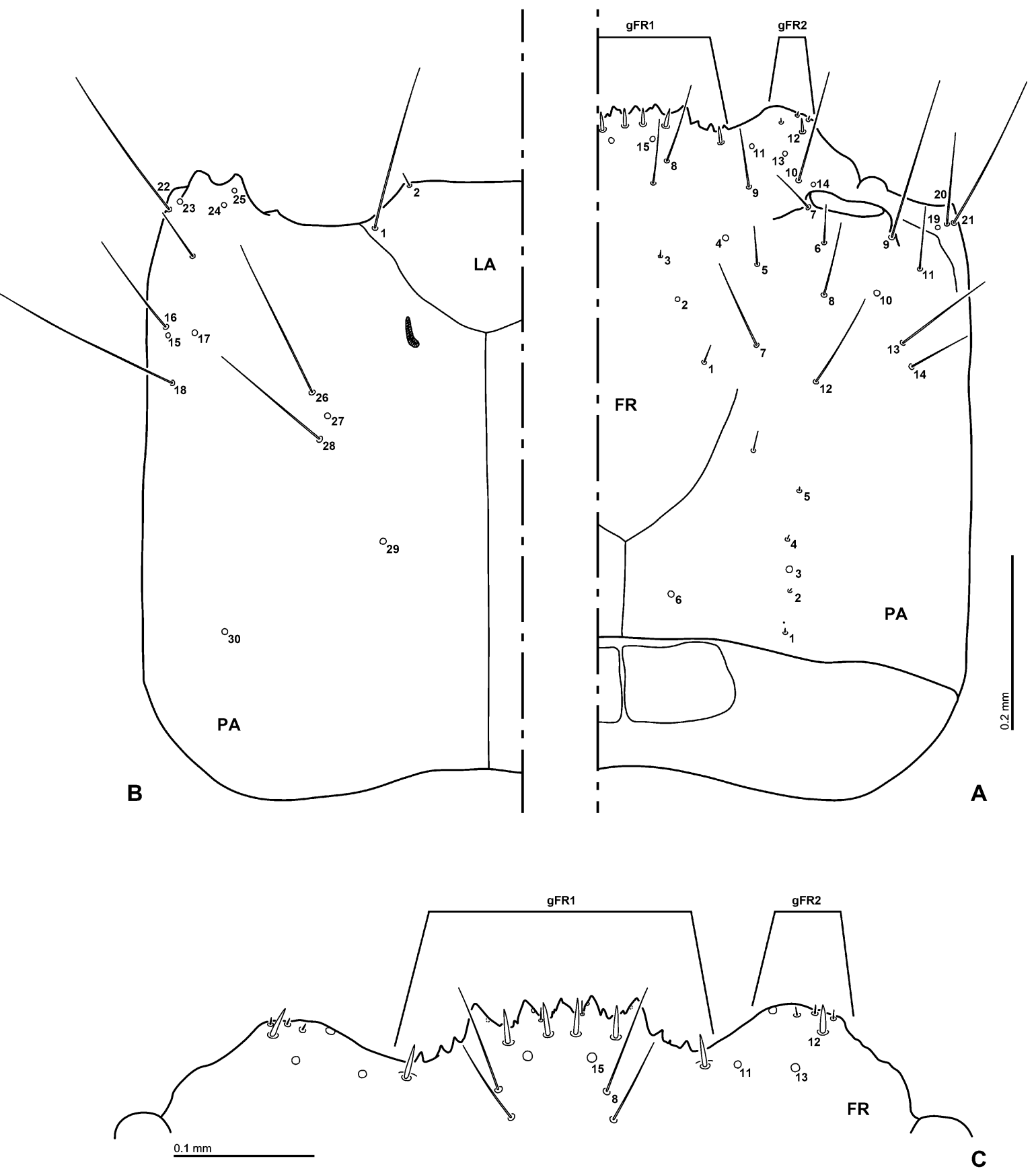

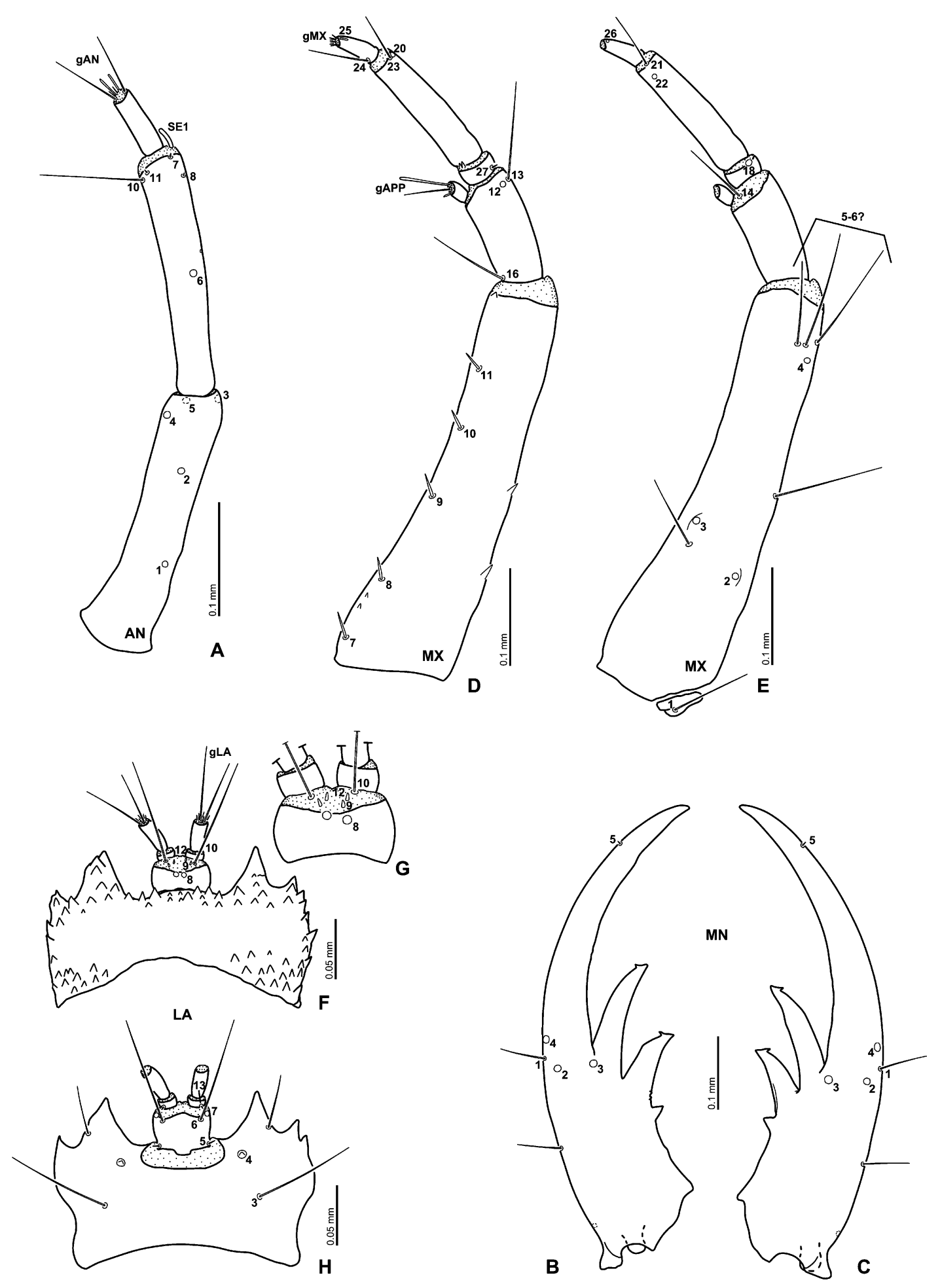


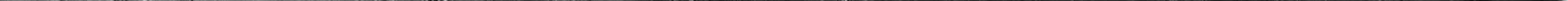

